\section{MEDICAL MEN IN PARLIAMENT.}

\section{To the Edator of THE LANCET.}

SIR, - Will you allow me to sav that $I$ am in entire agreement with Lieutenant-Colonel M. A. Collins's suggestion (The Lancet, Oct. 120h) that the Medico-Psychological Association should be represented on the Executive Committee formed on Oct. 1st "to further the election of medical men to the Huse of Commons." I know well the importance of that branch of medicine in its relation to State legislation, and I will take the first available opportunity to endeavour to attain his object. When Colonel Collins raised the question it was getting very late, the meeting had lasted considerably over two hours and was beginning to disperse, and I wished to avoid the risk of prolonged delay and discussion which similar suggestions made by members specially interested in other branches of medicine and surgery would certain!y have caused.

I am, Sir, yours faithfully, HevRy MorRIS.

Cavendish-square, London, W., Oet. 14th, 1918.

To the Editor of THE LANCET.

SIR, - Can anyone inform me why in the recently formed committee for "taking such steps as may be possible to further the election of medical men to the House of Oommons," there is no representative of the Suciety of Apothecaries? - I am, Sir, yours faithfully,

William H. KeSTEVen, L.S.A.

Kingston Hill, Surrey, Oct. 12th, 1918.

\section{NOTIFICATION OF INDIGENOUS MALARIA.}

To the Editor of THE LANCET.

SIR,-I should like to add a word to Professor Arthur Hall's letter of warning in your issue of Oct. 12th concerning the introduction of malaria into this country. Hitherto cases of malaria have been comparatively few, and the chance, therefore, of any given anopheline mosquito coming into contact with any given case has been somewhat remote. The conditions are now, or will shortly be, greatly changed; and $I$ am under the impression that people generally are not fully alive to the very wide distribution of the anopheline group of mosquitoes in these islands.

During the past two years I have paid considerable attention to this subject in my own district, and have discovered that in the woods aud river valleys in the eastern portion of this county anophelines are readily to be found, most commonly A maoulipennis ; but this summer I have also found colonies of $A$ plumbeus, and it is quite certain that the south-eastern portion of England is the normal habitat of a large number of anopheline mosquitoes, as is shown in the British Museum map, which probably understates the case owing to paucity of observers. I regret that the limitation of petrol has this year circumscribed my own observation to a much narrower field.

$$
\text { I am, Sir, yours faithfully, }
$$

JAMES 12 . WHITIVELI.

St. Audry's Hospital, Melton, Suffolk, Oet. 14th, 1918.

\section{CHRONIC INTESTINAL STASIS.}

To the Editor of THE LANCET.

SIR,-I can lay very little claim to the title of anatomist, and none at all to that of anthropologist. I am, therefore, clearly not in a position to discuss with Otptain F. Wood-Jones the interesting question as to whether or not the Hominida ever passed through a quadrupedal stage. I was taught that they did, but that proves nothing.

In the matter of "the damnable heritage of the colon," however, I crave a further word. If I have correctly understood your correspondent, he maintains that the short colon of the carnivora is adapted to the discipline of fasting, and the long colon of the herbivora to the otiose absorption of raw vegetables. I am quite content to take it at that. Now, man is furnished with a very long colon; but, in flagrant contravention of the formula, he eats flesh foods. Moreover, he cooks these flesh foods. He also cooks his vegetables, and mainly in such a manner as completely to destroy their vitamines. Such a degree of civilisation in matters dietetic may be very æsthetic, but it is obviously unsuited to the colon with which Providence has provided him. His colon, therefore, gives him very serious trouble. If he would avoid this trouble he must select one of two alternatives. He must either adapt his diet to his colon, or he must adapt his colon to his diet. The first he can do by confining himself to raw vegetables; the second he can accomplish either by fasting or by $h \star$ ving his colon shortened. He declines to live entirely on raw vegetables; and, having tried it, I cannot find it in me to blame him. The decision between fasting and colon removing is a mere matter of taste. Personally, I prefer the former.

I am, Sir, yours faithfully,

Harley-street, W., Oct. 12th, $1918 . \quad$ LeONARD Williams.

\section{SENSORY CHANGES IN THE DIAGNOSIS OF TRENCH FEVER.}

To the Editor of THE LANCET.

SIR,-The paper by Major Carmalt Jones in your issue of Oot. 5th is of very great interest. He has placed in our hands a helpful method of retrospective diagnosis of the original cause of much "debility." It would be interesting to know whether the absence of areas of increased sensitiveness in 20 per cent. of his series of 500 cases was ever associated with the presence of analgesic patches. Since my attention was called to such cases by Captain J. A. Hartley, R.A.M.C.(T.), I have investigated a large number and have found that it is quite common for men in the middle and later stages of the disease to have areas of analgesia to pin-prick. This loss of sensibility varies in degree from a mere blunting of sensation to complete analgesia. The most common situations for this phenomenon are the outer surface of the calf, the infrapatellar, scapular, and deltoid regions; it has not been found in the skin of the face, neck, or trunk. Circumstances have prevented investigation of the total duration of this sensory loss, but it has sometimes been found five weeks after the onset of the disease, and may still be present in a proportion of chronic cases readmitted to hospital from convalescent camps.

I am, Sir, yours faithfully,

France, Oct. 9th, 1918.
C. E SuNDELI Captain, R.A.M.C.

\section{intledical shetos.}

Society of Apothecaries of London.-At examinations recently beld the following candidates were successful in the subjects indicated :-

Primary himamation, Part il.

Anatomy.-J. W. Alden, Oxford; A. B. Aldred, Guy's Hosp. M. Buirski, London Hisp.; F. J. Darbyshire, King's Coll, Houp.; Hosp.: R J. Hooker, Guy's Husp.; C. F. Hong, Bristol; and A Senn. London $B$ isp

Physinl,gy.-A. B. Aldred, Guy's Hosp.; M. Buirski, London Hosp.; H. V. Uroucher, Guy's Aosp. I F. I. Darbyshire, King's Coll. Hosp. R. Erskine Gray and $\mathbf{E}$. W. Hieks, St. Thomass Hoso.; R. J.

Hooker, Guy's Hosp.: C. F. Long, Bristol; and A. Senn, London

Centrat Midwives Board.-A meeting of the Central Midwives Board was held at Queen Anne's Gate Buildings, Westminster, on Oet. 10th, with Sir Francis $H$. Champneys in the chair.-A letter was considered from the Local Government Board asking the Central Midwives Board to consider the advisability of framing a new Rule E. $22(1)(f)$ in terms similar to the corresponding rule of the Central Midwives Board for Scotland, which requires a midwife to notify the local supervisıng authority in the following case-* $(f)$ "Artificial feeding"-whenever under Rule 19 (b) she has advised the substitution of artificial feeding for breast feeding. 'The Board decided that the question be adjourned to the next meeting of the Board.-A letter was considered from the medical officer of health for the county of Durham asking whether the Board would object to the County Council supplying midwives within their jurisdiction with collosum argentum for the treatment of the eyes of newly born infants. The Board decided that the medical officer of health for the county of Durham be informed that the Board has designedly refrained from recommending in the rules the use of any specific drug for the treatment of the eyes of newly born infants. It sees no objection to the course proposed by the medical officer of health for the county of Durham.-A letter was considered from the acting county medical officer of health for the West Riding of Yorkshire bringing to the notice of the Board a scheme of maternity 